\title{
A let-7 microRNA polymorphism in the KRAS 3'-UTR is prognostic in oropharyngeal cancer
}

Citation for published version (APA):

De Ruyck, K., Duprez, F., Ferdinande, L., Mbah, C., Rios-Velazquez, E., Hoebers, F., Praet, M., Deron, P., Bonte, K., Speel, E-J., Libbrecht, L., De Neve, W., Lambin, P., \& Thierens, H. (2014). A let-7 microRNA polymorphism in the KRAS $3^{\prime}$-UTR is prognostic in oropharyngeal cancer. Cancer Epidemiology, 38(5), 591-8. https://doi.org/10.1016/j.canep.2014.07.008

Document status and date:

Published: 01/10/2014

DOI:

10.1016/j.canep.2014.07.008

Document Version:

Publisher's PDF, also known as Version of record

Document license:

Taverne

Please check the document version of this publication:

- A submitted manuscript is the version of the article upon submission and before peer-review. There can be important differences between the submitted version and the official published version of record.

People interested in the research are advised to contact the author for the final version of the publication, or visit the DOI to the publisher's website.

- The final author version and the galley proof are versions of the publication after peer review.

- The final published version features the final layout of the paper including the volume, issue and page numbers.

Link to publication

\footnotetext{
General rights rights.

- You may freely distribute the URL identifying the publication in the public portal. please follow below link for the End User Agreement:

www.umlib.nl/taverne-license

Take down policy

If you believe that this document breaches copyright please contact us at:

repository@maastrichtuniversity.nl

providing details and we will investigate your claim.
}

Copyright and moral rights for the publications made accessible in the public portal are retained by the authors and/or other copyright owners and it is a condition of accessing publications that users recognise and abide by the legal requirements associated with these

- Users may download and print one copy of any publication from the public portal for the purpose of private study or research.

- You may not further distribute the material or use it for any profit-making activity or commercial gain

If the publication is distributed under the terms of Article $25 \mathrm{fa}$ of the Dutch Copyright Act, indicated by the "Taverne" license above, 


\title{
A let-7 microRNA polymorphism in the KRAS $3^{\prime}$-UTR is prognostic in oropharyngeal cancer
}

\author{
Kim De Ruyck ${ }^{a, *}$, Fréderic Duprez ${ }^{b}$, Liesbeth Ferdinande ${ }^{c}$, Chamberlain Mbah ${ }^{a}$, \\ Emmanuel Rios-Velazquez ${ }^{\mathrm{d}}$, Frank Hoebers ${ }^{\mathrm{d}}$, Marleen Praet $^{\mathrm{c}}$, Philippe Deron ${ }^{\mathrm{e}}$, \\ Katrien Bonte ${ }^{\mathrm{e}}$, Ernst-Jan Speel ${ }^{\mathrm{f}}$, Louis Libbrecht ${ }^{\mathrm{c}}$, Wilfried De Neve ${ }^{\mathrm{b}}$, \\ Philippe Lambin ${ }^{\mathrm{d}}$, Hubert Thierens ${ }^{\mathrm{a}}$ \\ ${ }^{a}$ Department of Basic Medical Sciences, Ghent University, Proeftuinstraat 86, B-9000 Gent, Belgium \\ ${ }^{\mathrm{b}}$ Department of Radiotherapy, Ghent University Hospital, De Pintelaan 185, B-9000 Gent, Belgium \\ ${ }^{\mathrm{c}}$ Department of Pathology, Ghent University Hospital, De Pintelaan 185, B-9000 Gent, Belgium \\ ${ }^{\mathrm{d}}$ Department of Radiation Oncology (MAASTRO Clinic), GROW School for Oncology and Developmental Biology, Maastricht University Medical Center, Doctor \\ Tanslaan 12, 6229 ET Maastricht, The Netherlands \\ e Department of Head and Neck Surgery, Ghent University Hospital, De Pintelaan 185, B-9000 Gent, Belgium \\ ${ }^{\mathrm{f}}$ Department of Pathology, GROW School for Oncology and Developmental Biology, Maastricht University Medical Center, Doctor Tanslaan 12, 6229 ET \\ Maastricht, The Netherlands
}

\section{A R T I C L E IN F O}

\section{Article history:}

Received 14 May 2014

Received in revised form 16 July 2014

Accepted 23 July 2014

Available online 12 August 2014

\section{Keywords:}

Oropharyngeal cancer

HPV

Prevalence

Prognostic biomarker

Genetic polymorphisms

miRNA

KRAS

\begin{abstract}
A B S T R A C T
Introduction: This study aimed to investigate the effect of genetic polymorphisms in miRNA sequences, miRNA target genes and miRNA processing genes as additional biomarkers to HPV for prognosis in oropharyngeal squamous cell carcinoma (OPSCC) patients. Secondarily, the prevalence of HPVassociated OPSCC in a European cohort was mapped.

Methods: OPSCC patients ( $n=122$ ) were genotyped for ten genetic polymorphisms in pre-miRNAs (premir-146a, pre-mir-196a2), in miRNA biosynthesis genes (Drosha, XPO5) and in miRNA target genes (KRAS, SMC1B). HPV status was assessed by p16 immunohistochemistry (IHC) and high-risk HPV in situ hybridization (ISH) or by p16 IHC and PCR followed by enzyme-immunoassay (EIA). Overall and disease specific survival were analysed using Kaplan-Meier plots (log-rank test). Cox proportional hazard model was used to calculate hazard ratios (HR).

Results: The overall HPV prevalence rate in our Belgian/Dutch cohort was $27.9 \%$. Patients with $\mathrm{HPV}^{+}$ tumours had a better 5 -years overall survival $(78 \% v s .46 \%, p=0.001)$ and a better 5 -years disease specific survival ( $90 \%$ vs. $70 \%, p=0.016)$ compared to patients with $\mathrm{HPV}^{-}$tumours. In multivariate Cox analysis including clinical, treatment and genetic parameters, HPV negativity $(\mathrm{HR}=3.89, p=0.005)$, advanced Tstage $(\mathrm{HR}=1.81, p=0.050)$, advanced $\mathrm{N}$-stage $(\mathrm{HR}=5.86, p=0.001)$ and $>10$ pack-years of smoking $(\mathrm{HR}=3.45, p=0.012$ ) were significantly associated with reduced overall survival. The variant $\mathrm{G}$-allele of the KRAS-LCS6 polymorphism was significantly associated with a better overall survival $(\mathrm{HR}=0.40$, $p=0.031$.

Conclusions: Our results demonstrate that OPSCC patients with the KRAS-LCS6 variant have a better outcome and suggest that this variant may be used as a prognostic biomarker for OPSCC.
\end{abstract}

(c) 2014 Elsevier Ltd. All rights reserved.

\section{Introduction}

The increase in incidence of oropharyngeal squamous cell carcinoma (OPSCC) over the last 20 years has mainly been

\footnotetext{
* Corresponding author. Tel.: +32 92646656; fax: +32 92646696.

E-mail address: kim.deruyck@UGent.be (K. De Ruyck).
}

attributed to human papillomavirus (HPV) infection [1-3]. Depending on geographical location and time period studied, HPV prevalence rates in oropharyngeal cancer (OPC) range from $23 \%$ to $73 \%$ [4]. Among HPV-positive OPC, HPV16 is the predominant genotype, accounting for approximately 95\% of cases. HPV-associated OPSCC seems to be a distinct clinical entity with a better prognosis than HPV-negative tumours [5]. The strong prognostic effect of HPV status can be improved by combining it 
with smoking status and tumour and nodal stage [6,7]. Refining patient stratification by considering additional biomarkers next to HPV status and clinical parameters, may ensure appropriate therapy and therefore better survival and improved quality of life.

MicroRNAs (miRNAs) are endogenous short non-coding RNA molecules that regulate gene expression by binding to the $3^{\prime}-$ untranslated region (UTR) of protein coding transcripts, in turn triggering mRNA degradation or translational repression [8]. The biogenesis of miRNAs is a complex process involving multiple proteins. First, large primary precursors of miRNAs (pri-miRNA) are transcribed by RNA polymerase II and cleaved to miRNA precursor (pre-miRNAs) by the nuclear complex containing the RNASEN (Drosha) and DGCR8 proteins [9]. Then, the pre-miRNA is translocated to the cytoplasm through the assistance of RANGTPase and Exportin-5 (XPO5), where it is further processed by a protein complex including DICER, leading to the production of double-stranded miRNA duplex. Subsequently, one strand of miRNA is incorporated into RNA-induced silencing complex (RISC) including GEMIN3 and GEMIN4, which mediates expression of target genes [10]. It was estimated that a single miRNA can target hundreds of mRNAs and nearly $30 \%$ of protein-coding genes in the human genome can be regulated by miRNAs [11]. MiRNAs are involved in important biological processes related to apoptosis, proliferation, differentiation, angiogenesis and immune response [12]. Furthermore, miRNA expression alterations have been linked to initiation, progression, metastasis and treatment outcome of human cancers, including OPSCC $[13,14]$.

Genetic polymorphisms within miRNA sequences, target genes or processing genes are thought to have a functional impact on how miRNAs are active in tumours. The variant allele of the rs61764370 polymorphism in a let-7 miRNA complementary site (LCS6) of the KRAS 3'-UTR (KRAS-LCS6) has been shown to affect the survival of oral cancer patients [15]. The rs11614913 polymorphism of pre-mir-196a2 has been shown to enhance the survival of pharyngeal, oropharyngeal and oral cancer patients [16-18], and the pre-mir-146a rs2910164 polymorphism was shown to be prognostic for oropharyngeal cancer [17]. Several genetic variations in miRNA processing and target genes were found to be associated with the risk of second primary tumour and/or recurrence in patients with early stage head and neck cancer. The most significant variation, rs3747238, was located in a miRNA binding site of the SMC1B gene [19].

This study aimed to determine the prevalence of HPVassociated OPSCC in a European cohort and to investigate the effect of genetic polymorphisms in miRNA sequences, target genes and processing genes as additional markers to HPV for prognosis in OPSCC patients.

\section{Materials and methods}

\subsection{Study population}

The study population consisted out of 122 OPSCC patients treated between April 2003 and May 2012. Only patients receiving curative radiotherapy and from whom biological material was available, were included. A total of 57 patients were selected from the MAASTRO Clinic blood biobank database (The Netherlands) which prospectively collects blood samples of all patients scheduled for curative radiotherapy. Sixty-five patients treated at the Ghent University Hospital (Belgium) and participating in radiogenomics studies were also selected. The study was approved by the ethical committees of both centres and all study participants provided informed consent. The MAASTRO Clinic cohort study was filed at clinicaltrials.gov (no. NCT01084785).

Clinical, treatment and follow-up data were available in research databases. For every patient who was alive at the point of analysis but had not been seen in the clinic for the preceding 12 months, the general practitioner was contacted to ensure that the patient was still alive. Patients were classified as died by disease only if they had documented progressive or recurrent cancer. Clinical data and treatment details are presented in Table 1 . The majority of the patients were treated with intensity-modulated radiotherapy (IMRT) opposed to three-dimensional conformal radiotherapy (3DCRT) and computer-planned conventional radiotherapy with opposing latero-lateral fields and an anterior lowerneck field. The median total tumour dose was $69 \mathrm{~Gy}$ at 2.0$2.70 \mathrm{~Gy} /$ fraction (1 patient received $1.66 \mathrm{~Gy} /$ fraction). The details of the different radiotherapy treatment regimens can be found in the online supplement A. Forty-seven percent of the patients received platinum-based chemoradiotherapy. Eight patients (14\%) received daily low dose cisplatinum at $6 \mathrm{mg} / \mathrm{m}^{2}$ before each radiotherapy fraction. Four patients (7\%) were treated with weekly cisplatinum at $30 \mathrm{mg} / \mathrm{m}^{2}$. For 45 patients (79\%), cisplatinum at $100 \mathrm{mg} / \mathrm{m}^{2}$ was planned on days 1,22 and 43 . Due to toxicity, 15 patients only received two courses and 4 patients only received one course of cisplatinum.

\subsection{HPV detection}

HPV status was determined on formalin-fixed paraffin-embedded (FFPE) biopsy and resection material of OPSCC retrieved from the archives of the departments of pathology of both participating university hospitals. For the Gent patients, HPV infection was assessed by $\mathrm{p} 16$ immunohistochemistry (IHC) and high-risk HPV in situ hybridization (ISH). For the Maastricht patients, HPV infection was determined by p16 IHC and p16 positive samples were retested by PCR followed by enzyme-immunoassay (EIA).

\subsection{1. p16 immunohistochemistry}

p16 IHC was carried out on $1.5 \mu \mathrm{m}$ thick tissue sections using the CINtec $^{\circledR}$ p16 Histology (Ventana Medical Systems) on a BenchMark XT automated stainer (Ventana Medical Systems) under ISO15189:2007 (Gent) or CCKL (Maastricht) accreditation. p16 IHC was scored as positive if there was strong and diffuse nuclear and cytoplasmic staining present in more than $70 \%$ of tumour cells. All other staining patterns were scored as negative.

\subsubsection{GP5+/6+ PCR enzyme immunoassay}

Genomic DNA was extracted from $30 \mu \mathrm{m}$ thick tissue sections using the FFPE kit of Gentra Puregene (Qiagen, The Netherlands). HPV specific PCR with GP5+/6+ primers was performed. For samples without amplification, Specimen Control Size ladder was used for DNA quality control. HPV-typing was performed by EIA using a single probe for HPV type-16 and cocktails of probes for 14 high-risk $(16,18,31,33,35,39,45,51,52,56,58,59,66,68)$ and 4 low-risk $(6,11,40,42)$ HPV types. Assays were run in triplicate, with positive and negative controls.

\subsubsection{High-risk HPV in situ hybridization}

High-risk HPV ISH was performed on $2-3 \mu \mathrm{m}$ thick tissue sections using the Inform HPV III Family B probe (Ventana Medical Systems) on a BenchMark XT automated stainer (Ventana Medical Systems) under ISO15189:2007 accreditation. The probe cocktail detects HPV types 16,18, 31, 33, 35, 39, 45, 51, 52, 56, 58 and 66. The high-risk HPV ISH test was scored by a pathologist and was considered positive if a discrete, blue coloured, precipitated reaction product within the tumour cells was observed.

\subsection{Genotyping}

Two polymorphisms in pre-miRNAs (pre-mir-146a rs2910164, pre-mir-196a2 rs11614913), six polymorphisms in miRNA biosyn- 
Table 1

Characteristics of the study population in relation to outcome.

\begin{tabular}{|c|c|c|c|c|}
\hline & \multirow{2}{*}{$\begin{array}{l}n \\
122\end{array}$} & \multirow[t]{2}{*}{$\%$} & \multicolumn{2}{|c|}{ Overall survival } \\
\hline & & & Deaths & $\begin{array}{l}\% \text { surviving } \\
5 \text { years }^{\mathrm{a}}\end{array}$ \\
\hline \multicolumn{5}{|l|}{ Gender } \\
\hline Men & 99 & 81.1 & 50 & 52.8 \\
\hline Woman & 23 & 18.9 & 9 & 64.1 \\
\hline \multicolumn{5}{|l|}{ Age (years) } \\
\hline Median & 60.5 & & - & - \\
\hline Range & $37.2-77.9$ & & - & - \\
\hline \multicolumn{5}{|l|}{ Nicotine use } \\
\hline Never & 12 & 10.1 & 2 & 80.2 \\
\hline Ever & 107 & 89.9 & 56 & 51.3 \\
\hline Missing & 3 & & & \\
\hline \multicolumn{5}{|l|}{ Pack-years } \\
\hline$\leq 10$ & 23 & 21.1 & 5 & 73.2 \\
\hline$>10$ & 86 & 78.9 & 50 & 47.7 \\
\hline Missing & 13 & & & \\
\hline \multicolumn{5}{|l|}{ Alcohol use } \\
\hline Never & 11 & 9.5 & 4 & 52.6 \\
\hline Ever & 105 & 90.5 & 52 & 55.4 \\
\hline Missing & 6 & & & \\
\hline \multicolumn{5}{|l|}{ Drinks/week } \\
\hline$<10$ & 44 & 37.3 & 13 & 69.1 \\
\hline$\geq 10$ & 74 & 62.7 & 44 & 46.6 \\
\hline Missing & 4 & & & \\
\hline \multicolumn{5}{|l|}{ Subsite tumour } \\
\hline Tonsil & 55 & 45.1 & 25 & 58.3 \\
\hline Other & 67 & 54.9 & 34 & 51.4 \\
\hline \multicolumn{5}{|l|}{ T-stage } \\
\hline $1-2$ & 67 & 54.9 & 25 & 68.5 \\
\hline $3-4$ & 55 & 45.1 & 34 & 38.7 \\
\hline \multicolumn{5}{|l|}{$\mathrm{N}$-stage } \\
\hline $0-1-2 a$ & 45 & 37.5 & 14 & 76.2 \\
\hline $2 b-2 c-3$ & 75 & 62.5 & 44 & 39.6 \\
\hline Missing & 2 & & & \\
\hline \multicolumn{5}{|l|}{ Tumour HPV status } \\
\hline Positive & 34 & 27.9 & 6 & 78.0 \\
\hline Negative & 88 & 72.1 & 53 & 45.9 \\
\hline \multicolumn{5}{|l|}{ Treatment } \\
\hline $\mathrm{RT}^{\mathrm{b}}$ & 48 & 39.3 & 21 & 59.7 \\
\hline $\mathrm{RT}^{\mathrm{b}}+\mathrm{ChT}^{\mathrm{c}}$ & 49 & 40.2 & 26 & 43.5 \\
\hline Surgery + $\mathrm{RT}^{\mathrm{b}}$ & 17 & 13.9 & 9 & 70.6 \\
\hline Surgery $+\mathrm{RT}^{\mathrm{b}}+\mathrm{ChT}^{\mathrm{c}}$ & 8 & 6.6 & 3 & 48.6 \\
\hline \multicolumn{5}{|l|}{ Radiotherapy type } \\
\hline Non-IMRT & 37 & 30.3 & 18 & 64.9 \\
\hline IMRT & 85 & 69.7 & 41 & 48.5 \\
\hline \multicolumn{5}{|l|}{ Total tumour dose (Gy) } \\
\hline Median & 69.0 & & - & - \\
\hline Range & $66.0-81.0$ & & - & - \\
\hline \multicolumn{5}{|l|}{ Dose/fraction (Gy) } \\
\hline Median & 2.0 & & - & - \\
\hline Range & $1.66-2.70$ & & - & - \\
\hline Fractionation scheme & & & & \\
\hline Daily & 93 & 76.2 & 47 & 50.9 \\
\hline Hybrid $^{d}$ & 29 & 23.8 & 12 & 64.8 \\
\hline Treatment time $^{\mathrm{e}}$ (days & & & & \\
\hline Median & 44.0 & & - & - \\
\hline Range & $28.0-59.0$ & & - & - \\
\hline Centre & & & & \\
\hline Gent & 65 & 53.3 & 36 & 47.2 \\
\hline Maastricht & 57 & 46.7 & 23 & 62.6 \\
\hline
\end{tabular}

a Kaplan-Meier survival estimate.

b Radiotherapy.

c Chemotherapy.

d 22 fractions daily, last 12 fractions twice daily.

e Of (chemo)radiotherapy. thesis genes (Drosha: rs639174, rs3805500, rs10520985, rs17410035; XPO5: rs2227301, rs699937) and two polymorphisms in miRNA target genes (KRAS: rs61764370; SMC1B: rs3747238) were considered. Genomic DNA was obtained from blood using the Puregene genomic DNA purification kit (Gentra systems). Genotyping was performed using restriction fragment length polymorphism (RFLP) analyses, high resolution melting (HRM) curve analyses and/or direct sequencing. Primer sequences and restriction enzymes are available in the online Tables S1 and S2. For reproducibility control, $15 \%$ of all samples were duplicated. The concordance rate between duplicate samples was $100 \%$. The maximal number of missing values per polymorphism was three.

\subsection{Statistical methods}

Five-year survival was designated as a clinically relevant endpoint. Overall survival time was calculated from the date of primary treatment to the date of death from any cause; survivors were censored at their last follow-up. Disease specific survival time was calculated from the date of primary treatment to the date of death from disease; patients who died of other/unknown cause were censored at time of death, survivors were censored at their last follow-up. Patients that were lost from follow-up were censored. Survival plots and 5-year survival rates were obtained by Kaplan-Meier analysis, with comparisons between groups made by the log-rank test. The Cox proportional hazard model was used to estimate hazard ratio's (HR) characterizing the independent prognostic significance of single and multiple variables. To account for missing values, multiple imputation was used. Therefore, 100 datasets were imputed which allow for efficient computation of $p$ values. The best multivariate model was chosen by stepwise regression (both forward and backward) that minimizes the AIC (Akiake Information Criterion) score. Traditional methods that add significant terms based on F-statistics fail to account for multiple testing and hence do not capture important markers. Standard errors and $p$-values of the variables are derived from a combination of standard errors from sample variation and variation due to multiple imputation. All analyses were performed in $\mathrm{R}$ by applying the $R$ package mi for multiple imputation [20] and the survival package for Cox modelling [21]. Differences in distributions of selected characteristics between HPV-positive and HPV-negative patients were evaluated using $\chi^{2}$ or Mann-Whitney test in the SPPS software packet.

\section{Results}

\subsection{Patient characteristics}

The 122 patients included in this study (Table 1) were predominantly male $(81.1 \%)$, ever smokers with more than 10 pack-years (78.9\%) and represented primarily stage III/IV tumours (88.5\%). The overall median follow-up time was 46.7 months (range 2.4-119.7 months), during which period 59 patients died from any cause, 32 patients relapsed (local, regional or distant) and 27 patients died from the disease. The overall median follow-up time was 60.0 months for surviving patients (range 18.1-112.9 months) and 19.3 months for deceased patients (range 2.4-119.7 months). Five years overall survival and disease specific survival was $55 \%$ and $76 \%$, respectively.

\subsection{Characteristics of the studied genetic polymorphisms}

Ten genetic polymorphisms were determined for all patients. The minor allele frequencies of the pre-mir-146a rs2910164 and the pre-mir-196a2 rs11614913 polymorphisms were $29.2 \%$ and $40.0 \%$, respectively. The minor allele frequencies of the Drosha 
rs639174, rs3805500, rs10520985 and rs17410035 polymorphisms were $20.4 \%, 32.5 \%, 47.5 \%$ and $30.0 \%$, respectively. For the XPO5 rs2227301 and rs699937 polymorphisms, the KRAS rs61764370 and the SMC1B rs3747238 polymorphism, the minor allele frequencies were $26.5 \%, 33.3 \%, 9.6 \%$ and $40.4 \%$, respectively. All genotype distributions were in Hardy-Weinberg equilibrium $(p>0.156)$. The genotype frequencies of the studied genetic polymorphisms in relation to outcome are presented in Table 2 . In univariate analysis (log-rank and logistic regression) none of the considered genetic polymorphisms were significantly associated with overall survival (data not shown). As we aimed at considering all studied variables from the start of the analysis and at accounting for missing values and multiple testing, the methodology as described in Section 2.4 was used for variable selection and estimation of hazard ratios.

\subsection{Multivariate analysis for survival}

Multivariate Cox analysis including all clinical, treatment and genetic parameters was performed for 5-years overall survival (Table 3). A similar analysis for disease specific survival was unfeasible due to the low number of disease-related deaths. HPV negativity $(\mathrm{HR}=3.89, p=0.005)$, advanced $\mathrm{T}$-stage $(\mathrm{HR}=1.81$, $p=0.050)$, advanced $\mathrm{N}$-stage $(\mathrm{HR}=5.86, p=0.001)$ and $>10$ packyears of smoking ( $\mathrm{HR}=3.45, p=0.012)$ were significantly associated with reduced overall survival. Of all treatment factors included in the analysis, IMRT $(\mathrm{HR}=2.27, p=0.028)$ and longer treatment times $(\mathrm{HR}=1.78, p=0.050)$ were associated with an increased hazard of death. The wild-type genotype of the KRASLCS6 rs61764370 polymorphism (TT) was significantly associated with reduced overall survival ( $\mathrm{HR}=2.47, p=0.031)$. None of the other studied genetic polymorphisms were significantly associated with survival. The Kaplan-Meier plot in Fig. 1 demonstrates the added value, next to HPV status, of the KRAS-LCS6 polymorphism as prognostic marker in especially $\mathrm{HPV}^{-}$OPC patients. For patients with $\mathrm{HPV}^{-}$tumours, overall survival at 5 years was $60 \%$ for TG genotypes and $42 \%$ for TT genotypes $(p=0.050)$. A similar survival plot by HPV status and pack-years of smoking shows that HPV patients with $\leq 10$ pack-years had a mean 5-year overall survival rate comparable to $\mathrm{HPV}^{+}$patients, whereas a firm decrease in overall survival was seen for $\mathrm{HPV}^{-}$patients with $>10$ pack-years (Fig. 1).

\subsection{HPV prevalence and association with selected variables}

Tumours were classified as HPV-positive if they overexpressed p16 and contained DNA from high-risk HPV types (by PCR-EIA or ISH). The overall HPV prevalence rate was $27.9 \%$ (34/122) and the majority of infections (30/34) occurred in tonsil or base of tongue subsites (prevalence rates of $36.4 \%$ and $40.0 \%$, respectively). Among cases that tested positive for p16 IHC (41/122), 7 were negative for ISH (4/7) or PCR-EIA (3/7). This overestimation by p16 IHC of $17 \%$ is in accordance with literature [22]. None of the tumours were p16-negative/ISH-positive. Examples of p16 IHC/ HPV ISH positive and negative cases are given in Fig. 2.

The distribution of selected variables by tumour HPV status is presented in Table 4. There was no difference in age and gender between $\mathrm{HPV}^{+}$and $\mathrm{HPV}^{-}$OPSCC patients. Compared to $\mathrm{HPV}^{-}$ patients, $\mathrm{HPV}^{+}$patients had less tobacco $(>10$ pack-years: $51.9 \%$ vs. $87.8 \%, p<0.001$ ) and alcohol exposure ( $\geq 10$ drinks/week: $28.1 \%$ vs. $75.6 \%, p<0.001)$. More $\mathrm{HPV}^{+}$patients had lower T-stages $(p=0.079)$ and $\mathrm{HPV}^{+}$tumours occurred more frequently in the tonsils $(p=0.058)$. There were no differences in treatment regimens between $\mathrm{HPV}^{+}$and $\mathrm{HPV}^{-}$patients. $\mathrm{HPV}^{+}$patients had a better 5 -years overall survival ( $78 \% v s .46 \%, p=0.001)$ and a better 5 years disease specific survival $(90 \% v s .70 \%, p=0.016)$ compared to
Table 2

Genotype frequencies of the studied genetic polymorphisms in relation to outcome.

\begin{tabular}{|c|c|c|c|c|}
\hline & \multirow{2}{*}{$\begin{array}{l}n \\
122\end{array}$} & \multirow[t]{2}{*}{$\%$} & \multicolumn{2}{|c|}{ Overall survival } \\
\hline & & & Deaths & $\begin{array}{l}\% \text { surviving } \\
5 \text { years }^{\mathrm{a}}\end{array}$ \\
\hline \multicolumn{5}{|c|}{ pre-mir-146a rs2910164 } \\
\hline GG & 57 & 47.5 & 29 & 49.5 \\
\hline GC & 56 & 46.7 & 26 & 60.4 \\
\hline $\mathrm{CC}$ & 7 & 5.8 & 3 & 57.1 \\
\hline Missing & 2 & & & \\
\hline $\mathrm{MAF}^{\mathrm{b}}$ & & 29.2 & & \\
\hline \multicolumn{5}{|c|}{ pre-mir-196a2 rs11614913 } \\
\hline $\mathrm{CC}$ & 45 & 37.5 & 23 & 57.9 \\
\hline $\mathrm{CT}$ & 54 & 45.0 & 26 & 48.8 \\
\hline TT & 21 & 17.5 & 9 & 63.8 \\
\hline Missing & 2 & & & \\
\hline $\mathrm{MAF}^{\mathrm{b}}$ & & 40.0 & & \\
\hline \multicolumn{5}{|c|}{ Drosha rs639174 } \\
\hline GG & 74 & 61.7 & 36 & 53.7 \\
\hline GA & 43 & 35.8 & 20 & 57.1 \\
\hline AA & 3 & 2.5 & 2 & 66.7 \\
\hline Missing & 2 & & & \\
\hline $\mathrm{MAF}^{\mathrm{b}}$ & & 20.4 & & \\
\hline \multicolumn{5}{|c|}{ Drosha rs3805500 } \\
\hline $\mathrm{TT}$ & 54 & 45.0 & 28 & 54.9 \\
\hline TC & 54 & 45.0 & 24 & 57.5 \\
\hline $\mathrm{CC}$ & 12 & 10.0 & 6 & 43.7 \\
\hline Missing & 2 & & & \\
\hline $\mathrm{MAF}^{\mathrm{b}}$ & & 32.5 & & \\
\hline \multicolumn{5}{|c|}{ Drosha rs10520985 } \\
\hline $\mathrm{CC}$ & 35 & 29.2 & 15 & 58.9 \\
\hline $\mathrm{CT}$ & 56 & 46.7 & 28 & 51.7 \\
\hline TT & 29 & 24.2 & 15 & 57.0 \\
\hline Missing & 2 & & & \\
\hline $\mathrm{MAF}^{\mathrm{b}}$ & & 47.5 & & \\
\hline \multicolumn{5}{|c|}{ Drosha rs17410035 } \\
\hline $\mathrm{CC}$ & 58 & 48.3 & 28 & 56.0 \\
\hline CA & 52 & 43.3 & 26 & 53.8 \\
\hline $\mathrm{AA}$ & 10 & 8.3 & 4 & 60.0 \\
\hline Missing & 2 & & & \\
\hline $\mathrm{MAF}^{\mathrm{b}}$ & & 30.0 & & \\
\hline \multicolumn{5}{|c|}{ XPO5 rs2227301 } \\
\hline GG & 63 & 52.9 & 36 & 44.1 \\
\hline GA & 49 & 41.2 & 19 & 63.5 \\
\hline AA & 7 & 5.9 & 3 & 68.6 \\
\hline Missing & 3 & & & \\
\hline $\mathrm{MAF}^{\mathrm{b}}$ & & 26.5 & & \\
\hline \multicolumn{5}{|c|}{ XРО5 rs699937 } \\
\hline $\mathrm{CC}$ & 52 & 43.3 & 30 & 45.6 \\
\hline $\mathrm{CT}$ & 56 & 46.7 & 22 & 59.4 \\
\hline TT & 12 & 10.0 & 6 & 63.5 \\
\hline Missing & 2 & & & \\
\hline $\mathrm{MAF}^{\mathrm{b}}$ & & 33.3 & & \\
\hline \multicolumn{5}{|c|}{ KRAS rs61764370 } \\
\hline TT & 97 & 80.8 & 46 & 52.9 \\
\hline TG & 23 & 19.2 & 12 & 62.9 \\
\hline GG & 0 & 0 & 0 & - \\
\hline Missing & 2 & & & \\
\hline $\mathrm{MAF}^{\mathrm{b}}$ & & 9.6 & & \\
\hline \multicolumn{5}{|c|}{ SMC1B rs3747238 } \\
\hline AA & 40 & 33.3 & 18 & 54.5 \\
\hline AG & 63 & 52.5 & 32 & 53.6 \\
\hline GG & 17 & 14.2 & 8 & 52.9 \\
\hline Missing & 2 & & & \\
\hline $\mathrm{MAF}^{\mathrm{b}}$ & & 40.4 & & \\
\hline
\end{tabular}

\footnotetext{
a Kaplan-Meier survival estimate.
}

b Minor allele frequency.

$\mathrm{HPV}^{-}$patients. The $\mathrm{HPV}^{+}$ratio was significantly higher in Maastricht compared to Gent (36.8\% vs. 20.0\%, $p=0.038$ ) and increased over time (38.5\% before $v s .15 .8 \%$ since $2007, p=0.005$ ). 
Table 3

Multivariate analysis for risk of death from any cause.

\begin{tabular}{|c|c|c|c|c|}
\hline & \multirow[t]{2}{*}{ Subgroups } & \multicolumn{3}{|c|}{ Overall survival } \\
\hline & & HR & $95 \% \mathrm{CI}$ & $p$-Value \\
\hline Pack-years & $>10 \mathrm{PY}$ vs. $\leq 10 \mathrm{PY}$ & 3.45 & $1.32-9.09$ & 0.012 \\
\hline T-stage & $3 / 4$ vs. $1 / 2$ & 1.81 & $1.00-3.28$ & 0.050 \\
\hline $\mathrm{N}$-stage & $2 \mathrm{~b} / 2 \mathrm{c} / 3$ vs. $0 / 1 / 2 \mathrm{a}$ & 5.86 & $2.61-13.14$ & 0.001 \\
\hline HPV status & Negative vs. positive & 3.89 & $1.51-10.00$ & 0.005 \\
\hline Radiotherapy type technique & IMRT vs. 3DCRT & 2.27 & $1.09-4.72$ & 0.028 \\
\hline Treatment time $^{\mathrm{a}}$ & & 1.78 & $1.00-3.17$ & 0.050 \\
\hline KRAS-LCS6 rs61764370 & TT vs. TG & 2.47 & $1.09-5.62$ & 0.031 \\
\hline
\end{tabular}

a of (chemo)radiotherapy, continuous variable.
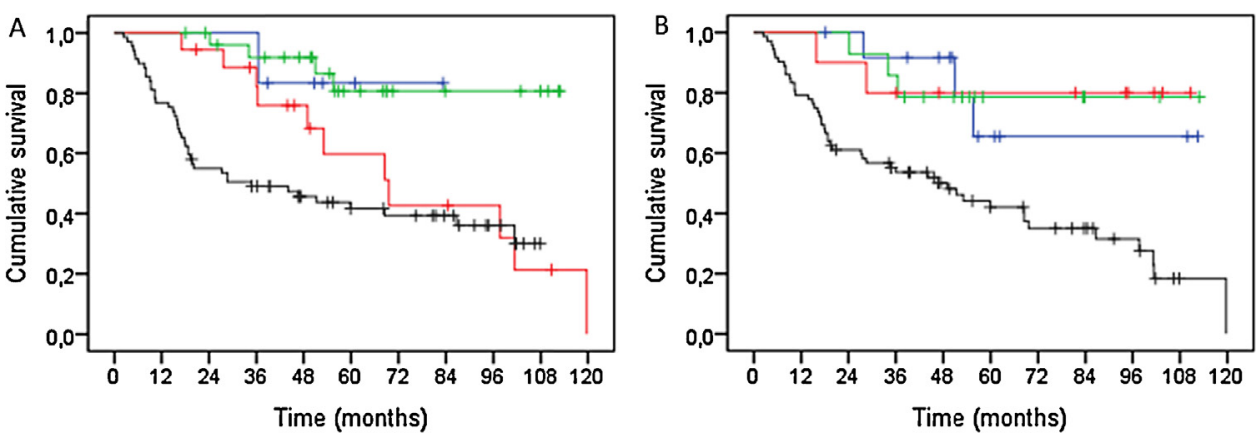

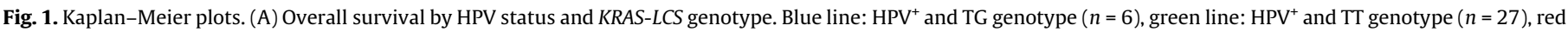

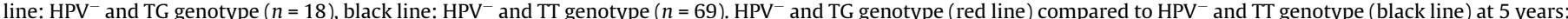

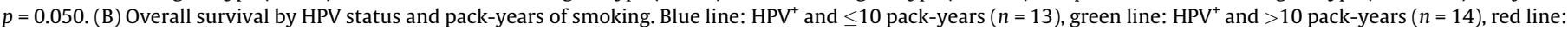

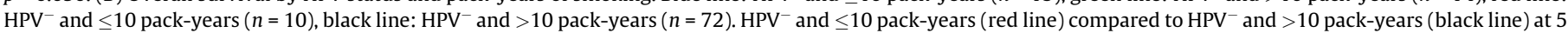
years: $p=0.056$. (For interpretation of the references to color in this figure caption, the reader is referred to the web version of the article.)

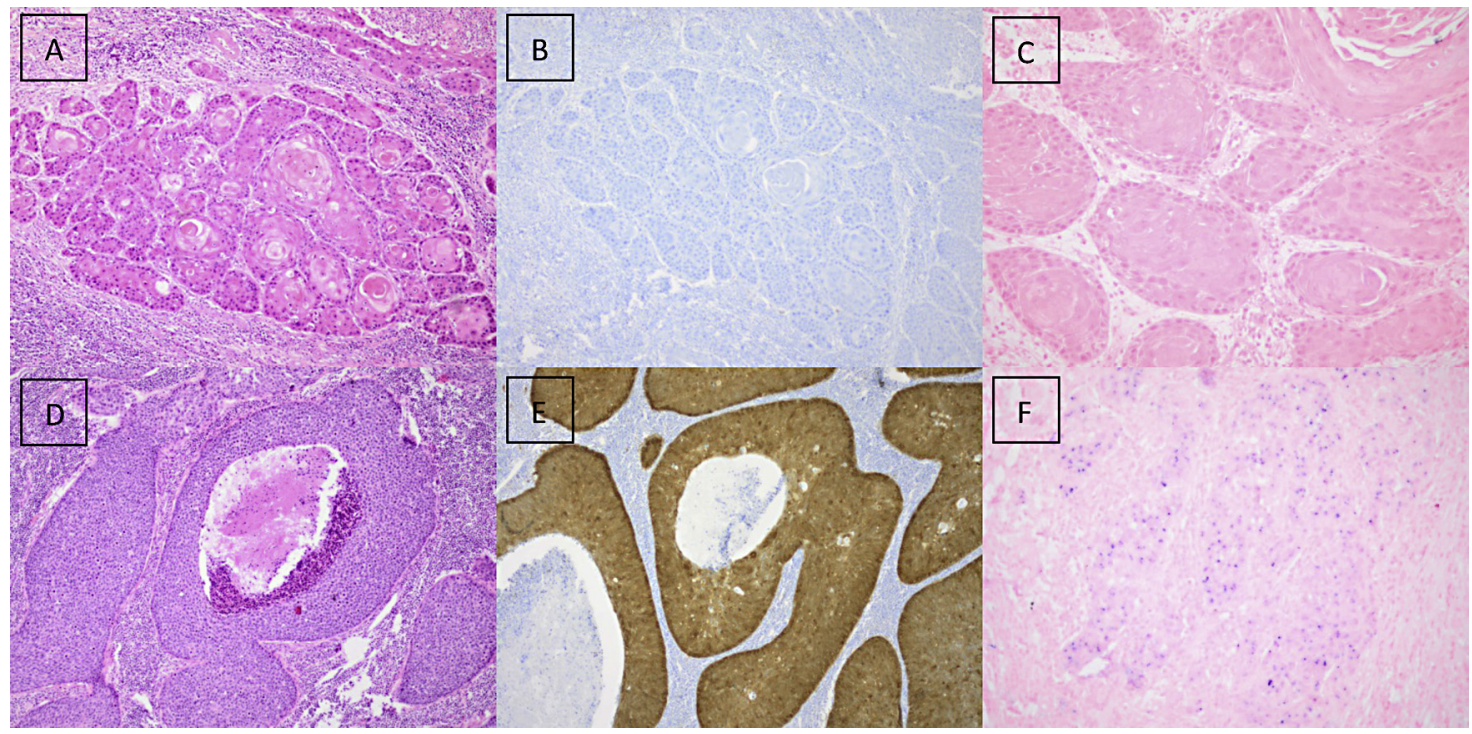

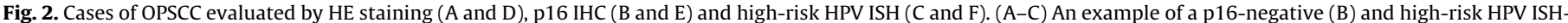
negative (C) case. (D-F) An example of a p16-positive (E) and high-risk HPV ISH-positive (F) case. Magnifications: $100 \times(\mathrm{A}, \mathrm{B}, \mathrm{D}, \mathrm{E}), 200 \times(\mathrm{C}$ and F).

The cut-off was based on the median start date of radiotherapy. HPV prevalence over time for the two geographical locations is further illustrated in Fig. 3.

\section{Discussion}

The survival of patients with advanced OPSCC may differ significantly between individuals. The ability to estimate survival probability before any type of treatment would be very valuable for decision making, as well as for developing clinical trials. Prior studies have demonstrated that positive HPV status confers an enormous prognostic benefit to patients. As additional biomarkers may help in refining patient stratification, we investigated the prognostic value of miRNA, miRNA-binding site and miRNA processing gene polymorphisms in OPC patients.

In our dataset, nodal stage, HPV status and smoking quantity were found to have the strongest impact on survival. Next to these known prognostic factors, the considered KRAS-LCS6 polymorphism was also significantly associated with prognosis of OPSCC. KRAS is a proto-oncogene that is activated by somatic mutation in many human cancers. KRAS mutation is more prevalent in colorectal (31\%) and non-small cell lung (19\%) cancer compared 
Table 4

Distribution of selected variables by tumour HPV status.

\begin{tabular}{|c|c|c|c|c|c|}
\hline & \multicolumn{2}{|c|}{$\begin{array}{l}\text { HPV positive } \\
\text { pts }(n=34)\end{array}$} & \multicolumn{2}{|c|}{$\begin{array}{l}\text { HPV negative } \\
\text { pts }(n=88)\end{array}$} & \multirow[t]{2}{*}{$p$-Value } \\
\hline & Number & $\%$ & Number & $\%$ & \\
\hline \multicolumn{6}{|l|}{ Gender } \\
\hline Men & 29 & 85.3 & 70 & 79.5 & \\
\hline Woman & 5 & 14.7 & 18 & 20.5 & 0.467 \\
\hline \multicolumn{6}{|l|}{ Age } \\
\hline Median & 61.8 & - & 60.2 & - & \\
\hline Range & $37.9-77.9$ & - & $37.2-77.3$ & - & 0.756 \\
\hline \multicolumn{6}{|l|}{ Pack-years } \\
\hline$\leq 10$ & 13 & 48.1 & 10 & 12.2 & \\
\hline$>10$ & 14 & 51.9 & 72 & 87.8 & $<0.001$ \\
\hline \multicolumn{6}{|l|}{ Drinks/week } \\
\hline$<10$ & 23 & 71.9 & 21 & 24.4 & \\
\hline$\geq 10$ & 9 & 28.1 & 65 & 75.6 & $<0.001$ \\
\hline \multicolumn{6}{|l|}{ Subsite tumour } \\
\hline Tonsil & 20 & 58.8 & 35 & 39.8 & \\
\hline Other & 14 & 41.2 & 53 & 60.2 & 0.058 \\
\hline \multicolumn{6}{|l|}{ T-stage } \\
\hline $1-2$ & 23 & 67.6 & 44 & 50.0 & \\
\hline $3-4$ & 11 & 32.4 & 44 & 50.0 & 0.079 \\
\hline \multicolumn{6}{|l|}{$\mathrm{N}$-stage } \\
\hline $0-1-2 \mathrm{a}$ & 12 & 35.3 & 33 & 38.4 & \\
\hline $2 b-2 c-3$ & 22 & 64.7 & 53 & 61.6 & 0.754 \\
\hline \multicolumn{6}{|l|}{ Treatment } \\
\hline $\mathrm{RT}^{\mathrm{a}}$ & 12 & 35.3 & 36 & 40.9 & \\
\hline $\mathrm{RT}^{\mathrm{b}}+\mathrm{ChT}^{\mathrm{b}}$ & 14 & 41.2 & 35 & 39.8 & \\
\hline Surgery + $\mathrm{RT}^{\mathrm{a}}$ & 4 & 11.8 & 13 & 14.8 & \\
\hline Surgery $+\mathrm{RT}^{\mathrm{a}}+\mathrm{ChT}^{\mathrm{b}}$ & 4 & 11.8 & 4 & 4.5 & 0.509 \\
\hline \multicolumn{6}{|l|}{ Centre } \\
\hline Gent & 13 & 38.2 & 52 & 59.1 & \\
\hline Maastricht & 21 & 61.8 & 36 & 40.9 & 0.038 \\
\hline \multicolumn{6}{|l|}{ Time span } \\
\hline 2003-2006 & 9 & 26.5 & 48 & 54.5 & \\
\hline 2007-2012 & 25 & 73.5 & 40 & 45.5 & 0.005 \\
\hline
\end{tabular}

a Radiotherapy.

b Chemotherapy.

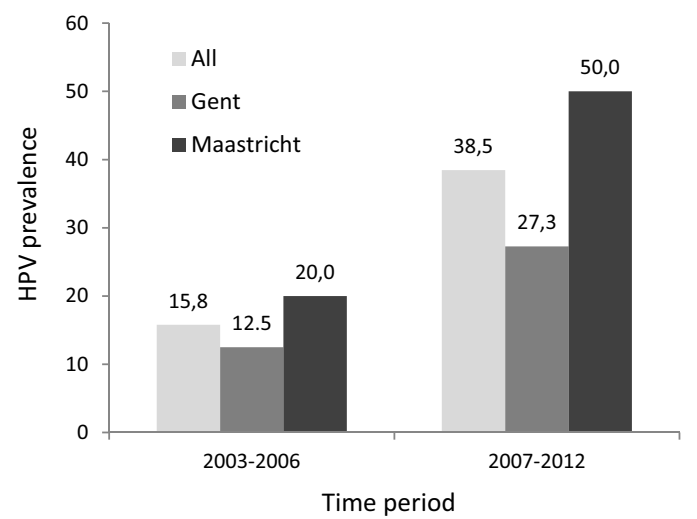

Fig. 3. HPV prevalence over time for the two geographical locations.

to oral and tonsil cancer (4\%) $[23,24]$. In addition to gene mutation, KRAS activity can be altered by the let-7 family of miRNAs. It has been shown that let-7 induces RAS downregulation after binding to specific sites in the $3^{\prime}$-UTR KRAS mRNA [25,26]. The rs61764370 polymorphism in KRAS-LCS6 affects let-7-mediated regulation of KRAS expression. In lung cancer cell lines, the variant G-allele was observed to lead to higher KRAS levels and lower let-7 levels as compared to the wild type [27]. A reduction in let-7 miRNA expression levels was also observed in a colorectal cancer cell line harbouring the variant G-allele but no change in KRAS protein expression was observed [28]. G-allele carriers have been shown to have an increased lung cancer risk in moderate smokers [27], an increased ovarian cancer risk [29] and an increased triple-negative breast cancer risk [30]. Furthermore, the variant G-allele has been associated with reduced survival in oral cancer but not in pharyngeal, lung and ovarian cancer [15,31,32]. For colorectal cancer, both Smits et al. [33] and Ryan et al. [34] reported a better survival for patients with the variant G-allele, albeit Smits et al. only for early-stage tumours and Ryan et al. only for late-stage tumours. For the latter studies, differences in KRAS mutation and therapy could have modulated the impact of the polymorphism. In the present study, we also found a significant survival advantage for G-allele carriers in our oropharyngeal study population. As mentioned above, Christensen et al. did not observe an altered survival pattern for pharyngeal cancer patients - which were not exclusively oropharyngeal - in relation to the KRAS polymorphism, but did find a worse prognosis for oral cancer cases with the KRAS polymorphism [15]. As normal oral and pharyngeal epithelium are different cell types with specific transcriptomes, alterations in let7 family miRNA expression will impact expression of miRNA target transcripts in a cell type specific way. Hence, differential dysregulation of miRNA targets could explain the differential findings between both studies.

One of the remarkable findings was that patients treated with non-IMRT techniques had a survival advantage compared to patients treated with IMRT. This can be explained by the interaction of treatment type with T- and N-stage; more patients with higher stadia were treated with IMRT. Furthermore, patients with shorter treatment times had significantly better survival rates. Of all factors possibly influencing treatment time, only fractionation scheme was significantly associated with it (mean $\mathrm{TT}_{\text {daily }}=45.0$ days, mean $\mathrm{TT}_{\text {hybrid }}=36.8$ days, $p<0.001$ ). Patients receiving a hybrid fractionation scheme indeed had a better 5 years overall survival ( $65 \%$ vs. $51 \%, p=0.184)$ and a better 5 -years disease specific survival ( $92 \% v s .71 \%, p=0.026$ ) compared to patients receiving daily fractionations. Despite the fact that in current dataset more patients with small tumours were treated with a hybrid fractionation scheme, it is well-known that shortening of treatment time reduces accelerated proliferation in tumours and improves outcome [35].

As HPV prevalence rates differ between different geographical regions and time periods, we wanted to map the prevalence of HPV-associated OPC in a Belgian/Dutch cohort. The prevalence rate in this study was $28 \%$ for all patients, $20 \%$ for patients in the North of Belgium and $37 \%$ for patients in the South of the Netherlands. The large difference between sites was not caused by selection bias. Oropharyngeal cancer caused by HPV increased from $16 \%$ in 2003-2006 to 39\% in 2007-2012. These rates are comparable to a Dutch series (19\%, 2000-2006, [36]) but significantly lower than UK (55\%, 2001-2006, [37]) and US (59\%, 2002-2005, [7]) series. Considering the rapid increase in prevalence in our dataset, it is expected that prevalence rates resembling those of other regions will be reached between 10 and 20 years.

In conclusion, HPV was detected in $28 \%$ of OPSSC in this study. OPC patients with the KRAS-LCS6 variant allele showed to have a survival advantage suggesting that, if externally validated, this variant may be used as an additional prognostic marker for OPSCC.

\section{Funding}

Support for this study was provided by grants of the Research Foundation Flanders (FWO) (no. 09/PDO/061 and 13/PDOH1/061). The authors also acknowledge financial support from EU 7th 
framework program (EURECA, ARTFORCE) and NGI Pre-Seed grant (no. 93612005).

\section{Conflicts of interest}

The authors declare that they have no conflicts of interest.

\section{Authorship contribution}

Kim De Ruyck: contributions to the conception, design, acquisition, analysis and interpretation of data; drafting of the manuscript; final approval of the manuscript.

Fréderic Duprez: contributions to the acquisition and interpretation of data; critical manuscript revising, final approval of the manuscript.

Liesbeth Ferdinande: contributions to the design and acquisition; critical manuscript revising; final approval of the manuscript.

Chamberlain Mbah: substantial contributions to the analysis; critical manuscript revising; final approval of the manuscript.

Emmanuel Rios Velazquez: contributions to the acquisition; critical manuscript revising; final approval of the manuscript.

Frank Hoebers: contributions to the acquisition and interpretation of data; critical manuscript revising; final approval of the manuscript.

Marleen Praet: contributions to the design and interpretation of data; critical manuscript revising; final approval of the manuscript.

Philippe Deron: contributions to the acquisition; critical manuscript revising; final approval of the manuscript.

Katrien Bonte: contributions to the acquisition; critical manuscript revising, final approval of the manuscript.

Ernst-Jan Speel: contributions to the acquisition and interpretation of data; critical manuscript revising; final approval of the manuscript.

Louis Libbrecht: contributions to the interpretation of data; critical manuscript revising; final approval of the manuscript.

Wilfried De Neve: contributions to the interpretation of data; critical manuscript revising; final approval of the manuscript.

Philippe Lambin: contributions to the conception and interpretation of data; critical manuscript revising; final approval of the manuscript.

Hubert Thierens: contributions to the conception, design and interpretation of data; critical manuscript revising; final approval of the manuscript.

\section{Acknowledgments}

The authors acknowledge the work of Joke Werbrouck, Laura De Backer, Amber De Smet and Lisa Vanlangendonck.

\section{Appendix A. Supplementary data}

Supplementary data associated with this article can be found, in the online version, at http://dx.doi.org/10.1016/j.canep.2014.07.008

\section{References}

[1] Braakhuis BJ, Visser O, Leemans CR. Oral and oropharyngeal cancer in The Netherlands between 1989 and 2006: increasing incidence, but not in young adults. Oral Oncol 2009;45:e85-9.

[2] Nasman A, Attner P, Hammarstedt L, Du J, Eriksson M, Giraud G, et al. Incidence of human papillomavirus (HPV) positive tonsillar carcinoma in Stockholm, Sweden: an epidemic of viral-induced carcinoma. Int J Cancer 2009;125:362_ 6

[3] Chaturvedi AK, Engels EA, Pfeiffer RM, Hernandez BY, Xiao W, Kim E, et al. Human papillomavirus and rising oropharyngeal cancer incidence in the United States. J Clin Oncol 2011;29:4294-301.
[4] Mehanna H, Beech T, Nicholson T, El-Hariry I, McConkey C, Paleri V, et al. Prevalence of human papillomavirus in oropharyngeal and nonoropharyngeal head and neck cancer - systematic review and meta-analysis of trends by time and regions. Head Neck 2013;35:747-55.

[5] Marur S, D'Souza G, Westra WH, Frastiere AA. HPV associated head and neck cancer: a virus-related cancer epidemic. Lancet Oncol 2010;11:781-9.

[6] Hafkamp HC, Manni JJ, Haesvoets, Voogd AC, Schepers M, Bot FJ, et al. Marked differences in survival rate between smokers and nonsmokers with HPV 16associated tonsillar carcinomas. Int J Cancer 2008:122:2656-64.

[7] Ang KK, Harris J, Wheeler R, Weber R, Rosenthal DI, Nguyen-Tân PF, et al. Human papillomavirus and survival of patients with oropharyngeal cancer. $\mathrm{N}$ Engl J Med 2010;363:24-35.

[8] Bartel DP. MicroRNAs: genomics, biogenesis, mechanism, and function. Cell 2004;116:281-97.

[9] Lee Y, Ahn C, Han J, Choi H, Kim J, Yim J, et al. The nuclear RNase III Drosha initiates microRNA processing. Nature 2003;425:415-9.

[10] Lee Y, Jeon K, Lee JT, Kim S, Kim VN. MicroRNA maturation: stepwise processing and subcellular localization. EMBO J 2002;21:4663-70.

[11] Lewis BP, Burge CB, Bartel DP. Conserved seed pairing, often flanked by adenosines, indicates that thousands of human genes are microRNA targets. Cell 2005;120:15-20

[12] Ruan K, Fang X, Ouyang G. MicroRNAs: novel regulators in the hallmarks of human cancer. Cancer Lett 2009:285:116-26.

[13] Nagadia R, Pandit P, Coman WB, Cooper-White J. Punyadeera C. miRNAs in head and neck cancer revisited. Cell Oncol 2013;36:1-7.

[14] Nohata N, Hanazawa T, Kinoshita T, Okamoto Y, Seki N. MicroRNAs function as tumor suppressors or oncogenes: aberrant expression of microRNAs in head and neck squamous cell carcinoma. Auris Nasus Larynx 2013;40:143-9.

[15] Christensen BC, Moyer BJ, Avissar M, Ouellet LG, Plaza SL, McClean MD, et al. A let-7 microRNA-binding site polymorphism in the KRAS $3^{\prime}$ UTR is associated with reduced survival in oral cancers. Carcinogenesis 2009;30:1003-7.

[16] Christensen BC, Avissar-Whiting M, Ouellet LG, Butler RA, Nelson HH, McClean MD, et al. Mature microRNA sequence polymorphism in MIR196A2 is associated with risk and prognosis of head and neck cancer. Clin Cancer Res 2010; $16: 3713-20$

[17] Guan X, Sturgis EM, Song X, Liu Z, El-Naggar AK, Wei Q, et al. Pre-microRNA variants predict HPV16-positive tumors and survival in patients with squamous cell carcinoma of the oropharynx. Cancer Lett 2013;330:233-40.

[18] Liu CJ, Tsai MM, Tu HF, Lui MT, Cheng HW. Lin SC miR-196a overexpression and miR-196a2 gene polymorphism are prognostic predictors of oral carcinomas. Ann Surg Oncol 2013:20(Suppl. 3):S406-14

[19] Zhang X, Yang H, Lee JJ, Kim E, Lippman SM, Khuri FR, et al. MicroRNA-related genetic variations as predictors for risk of second primary tumor and/or recurrence in patients with early-stage head and neck cancer. Carcinogenesis 2010;31:2118-23

[20] Su YS, Gelman A, Hill J, Yajima M. Multiple imputation with diagnostics (mi) in R: opening windows into the black box. J Stat Softw 2011;45:1-31.

[21] Therneau T. A package for survival analysis in S. R package version 2. 37-7; 2014, Available at http://CRAN.R-project.org/package=survival.

[22] Rietbergen MM, Snijders PJ, Beekzada D, Braakhuis BJ, Brink A, Heideman DA, et al. Molecular characterization of p16-immunopositive but HPV DNA-negative oropharyngeal carcinomas. Int J Cancer 2013;134:2366-72.

[23] Lea IA, Jackson MA, Li X, Bailey S, Peddada SD, Dunnick JK. Genetic pathways and mutation profiles of human cancers: site- and exposure-specific patterns. Carcinogenesis 2007:28:1851-8.

[24] Van Damme N, Deron P, Van Roy N, Demetter P, Bols A, Van Dorpe J, et al. Epidermal growth factor receptor and K-RAS status in two cohorts of squamous cell carcinomas. BMC Cancer 2010;10:189.

[25] Johnson SM, Grosshans H, Shingara J, Byrom M, Jarvis R, Cheng A, et al. RAS is regulated by the let-7 microRNA family. Cell 2005;120:635-47.

[26] Jerome T, Laurie P, Louis B, Pierre C. Enjoy the silence: the story of let-7 microRNA and cancer. Curr Genomics 2007;8:229-33.

[27] Chin LJ, Ratner E, Leng S, Zhai R, Nallur S, Babar I, et al. A SNP in a let-7 microRNA complementary site in the KRAS $3^{\prime}$ untranslated region increases non-small cell lung cancer risk. Cancer Res 2008;68:8535-40.

[28] Crowley EH, Arena S, Lamba S, Nicolantonio FD, Bardelli A. Targeted knock-in of the polymorphism rs61764370 does not affect KRAS expression but reduces let-7 levels. Hum Mutat 2014;35:208-14.

[29] Ratner E, Lu L, Boeke M, Barnett R, Nallur S, Chin LJ, et al. A KRAS variant in ovarian cancer acts as a genetic marker of cancer risk. Cancer Res 2010;70:6509-15.

[30] Paranjape T, Heneghan H, Lindner R, Keane FK, Hoffman A, Hollestelle A, et al. A 3 '-untranslated region KRAS variant and triple-negative breast cancer: a casecontrol and genetic analysis. Lancet Oncol 2011;12:377-86.

[31] Nelson HH, Christensen BC, Plaza SL, Wiencke JK, Marsit CJ, Kelsey KT. KRAS mutation, KRAS-LCS6 polymorphism, and non-small cell lung cancer. Lung Cancer 2010;69:51-3.

[32] Caiola E, Rulli E, Fruscio R, Buda A, Broggini M, Marabese M. KRas-LCS6 polymorphism does not impact on outcomes in ovarian cancer. Am J Cancer Res 2012;2:298-308.

[33] Smits KM, Paranjape T, Nallur S, Wouters KA, Weijenberg MP, Schouten LJ, et al. A let-7 microRNA SNP in the KRAS 3'UTR is prognostic in early-stage colorectal cancer. Clin Cancer Res 2011;17:7723-31. 
[34] Ryan BM, Robles AI, Harris CC. KRAS-LCS6 genotype as a prognostic marker in early-stage CRC. Clin Cancer Res 2012;18:3487-8.

[35] Bourhis J, Overgaard J, Audry H, Ang KK, Saunders M, Bernier J, et al. Hyperfractionated or accelerated radiotherapy in head and neck cancer: a metaanalysis. Lancet 2006;368:843-54

[36] Rietbergen MM, Brakenhof RH, Bloemena E, Witte BI, Snijders PJ, Heideman $\mathrm{DA}$, et al. Human papilloma virus detection and comorbidity: critical issues in selection of patients with oropharyngeal cancer for treatment de-escalation trials. Ann Oncol 2013;24:2740-5.

[37] Evans M, Newcombe R, Fiander A, Powell J, Rolles M, Thavaraj S, et al. Human papillomavirus-associated oropharyngeal cancer: an observational study of diagnosis, prevalence and prognosis in a UK population. BMC Cancer 2013;13:220. 